\title{
Gender Differences in HIV Risk Perception and Sexual Behaviour of Young Adults in Metropolitan Areas of Fiji
}

https://doi.org/10.33318/jpacs.2019.39(1)-05

Gurmeet Singh ${ }^{1}$, Aarti Sewak ${ }^{2}$, Karuna G. Reddy ${ }^{3}$, Sharan Ram ${ }^{4}$

\begin{abstract}
This study seeks to understand variations in Human Immunodeficiency Virus (HIV) risk perception and sexual behaviour among male and female adults in Fiji. The Second-Generation Surveillance Report (2006) indicates the median age of first sex within the youth group as 16 years (range $10-23$ years). Therefore, this study was purposively targeted at individuals of reproductive age, preferably 10 years and above. We utilized convenience sampling to collect 137 self-administered surveys from individuals working in both public and private sector organizations in two highly populated areas of Fiji. Independent samples t-test analyses revealed that men living in urban areas are more likely to experiment with multiple sexual partners, have a higher tendency of engaging in sexual practices, and are highly likely to have unsafe sex with multiple partners. Gender-sensitive interventions may help facilitate and achieve positive behaviour change among males and influence the sexual health of females.
\end{abstract}

Keywords: Fiji; Gender Differences; HIV; Sexual Behaviour; Sexual Health

${ }^{1}$ Corresponding author: Professor, Head of the Graduate School of Business (GSB), and Director of Master of Business Administration programme, The University of the South Pacific, Fiji, email: singh_g@usp.ac.fj

${ }^{2}$ Research Scholar, Griffith University, Australia, email: a.sewak@griffith.edu.au

${ }^{3}$ Research Fellow (Survey Statistics), Centre for Social Research \& Methods, College of Arts \& Social Sciences, Australia National University, Australia, email: Karuna.Reddy@anu.edu.au

${ }^{4}$ Fiji National University, Suva, Fiji. Email: shrnsatish@ hotmail.com 


\section{Introduction}

The prevalence of sexually transmitted infections (STI) among young adults is relatively high in the Pacific (Hammar, Gucake, \& Strobel, 2013; UNICEF Pacific, 2013). In fact, the Western Pacific Region has the highest median rate of gonorrhoea cases among adult men $(52.4$ per 100,000) when compared to the median case rate reported across 64 countries (18.8 per 100,000) in 2016-2017 (WHO, 2018a). STI rates among Pacific women is also alarming. Latest reports from the World Health Organization (2018b) indicate that one in three women visiting antenatal clinics in Vanuatu has reported some form of STI, the common one being Chlamydia infection and Trichomoniasis reported mostly among women below the age of 25 years. Similarly, more than 70 percent of STI cases in Fiji are reported among young people aged between 15 to 25 years (WHO, 2018b). The presence of STI increases the risk and transmission of HIV (Secretariat of the Pacific Community, 2010). Fiji has low HIV prevalence, estimated to be $0.1 \%$ for the adult population in 2016 (UNICEF Pacific, 2013). At the end of 2016, a total of 730 individuals were living with HIV/AIDS in Fiji (WHO, 2018b). The Ministry of Health (2014) reports that HIV is predominantly spread through young adults and transmitted via heterosexual contact.

Social and epidemiological research to date offer useful insights into the sexual attitudes and expectations of Fijian men (for instance, Kaitani, 2000, 2003), Fijians' self-assessments of HIV transmission risks (Hammar et al., 2011), the context in which risky behaviours occur (Buchanan-Aruwafu, 2007), and the factors that potentially fuel the HIV epidemic in Fiji (see ADB, 2006; UNAIDS et al., 2010; UNAIDS, 2012; UNGASS, 2010). Few studies, however, have conducted advanced comparative analyses of men's and women's sexual attitudes, risk perception ${ }^{1}$, and behaviour associated with HIV infection. Given that HIV transmission is predominantly through heterosexual contact (UNAIDS, 2012), the present study seeks to explore whether there are significant gender differences in men's and women's sexual attitudes, HIV risk perceptions, and protective behaviour in Fiji. Analysis of this type will help in determining the need for gender-specific HIV interventions.

\section{Gender and HIV}

Sexual attitudes and behaviours are strongly shaped by social constructions of gender (Ricardo et al., 2006). Adolescent risky sexual behaviours, such as having multiple

\footnotetext{
${ }^{1}$ Risk perception refers to an individual's personal assessment of vulnerability to contracting HIV. In HIV prevention work, segmenting audiences on the basis of risk perceptions and efficacy beliefs provides a heuristic model for developing well-targeted messages (Rimal et al., 2009).
} 
sexual partners and having unprotected sex, represents a serious public health concern (Yoon, Voithb, \& Kobulskyc, 2018). Mensch, Bruce, \& Greene (1998), and UNFPA (2005) recognise gender as a key issue for understanding the sexual behaviour of people, and there is an urgent need for this to be incorporated into the design of sexual health programs (Boender et al., 2004; Schueller, Finger, \& Barker, 2005). A recent study regarding the delivery of sexuality education in Fijian secondary schools shows that male and female students prefer sexual-health education to be delivered separately to them, particularly with regards to sensitive topics such as conception and contraception (Ram, 2018).

Social biologists have long associated gender differences in human sexual behaviour to variations in physiology, social, and cognitive elements (De Gaston, Weed, \& Jensen, 1996). Recent research by Techasrivichien et al. (2016) and Morrison (2004) ascertain that patterns of sexual behaviour and attitudes vary substantially across generations and across gender. Pan et al. (2016) also found significant gender differences in sexual risk behaviours. Some studies attribute gender differences to the impact of social and intimate relationships on behaviour (DiClemente et al, 2009).

Gender roles and relations significantly influence an individual's risk of exposure and vulnerability to HIV infection (Lerdboon et al., 2008). Discussions on gender have too often ignored the gender-specific challenges and vulnerabilities of men (Mensch et al., 1998). Looking at the notions of masculinity, for instance, men who engage in risky sexual behaviour to express their machismo (Meleisea, 2010; USAID, 2009; Varga, 2001) are likely to avoid seeking support services or social networks to discuss their HIV risk (CPHA, 2001). The results of a study conducted by Whitley (1988) indicate that sexual behaviour is influenced both by societal gender role norms and by individual differences in the acceptance of those norms. Societal norms surrounding male-female behaviour allow for boys to succumb to their desire for sex, while girls are encouraged to stay virgins until marriage (Nahom et al., 2001). Given this acceptance of their sexual freedom, it is not uncommon for men to report a greater number of sexual partners compared to women (Wiederman, 1997).

Some studies have found that males tend to initiate sexual activity at an earlier age than females (Browning, Hatfield, Kessler, and Levine, 2000). Moreover, as compared to women, men are less likely to negotiate safer sex practices (CPHA, 2001) because many young women have been socialised to accept male control of sexual decision-making including the use condoms (Harrison, Xaba, \& Kunene, 2001). According to Varga (2001), men are equally as likely as women, if not more 
so, to behave in ways that place both themselves and their partners at risk of sexual and reproductive health complications. Absalon et al., (2006) compared sexual behaviours and determined sexual risk correlates associated with HIV by gender among street-recruited drug users and found that men reported higher-risk sexual behaviours as compared to women. Looking at these differences, Sun et al., (2018) suggest that interventions should address gender differences and consider offering parallel interventions.

\section{Gender Norms in Fiji}

Throughout Pacific Island Countries (PICs), unequal gender relations and genderbased violence pose serious problems that aid the spread of HIV (Meleisea, 2010). Studies indicate that Pacific women tend to have less independence and fewer opportunities than men in matters pertaining to economic growth, property ownership and sexuality (Meleisea, 2010). Prevailing ideologies of gender inequality and masculinity have provided men with more social power and sexual license than women (Meleisea, 2010). Fijian men's sexual freedom is clearly portrayed in the study by McMillan and Worth (2010), who found that clients of sex workers in Fiji were exclusively males from all professional and ethnic groups. Furthermore, recent research by Lincoln, Mohammadnezhad, and Khan (2018) ascertain that male dominance over female sexuality continues to be a problem in Fijian communities.

Evidently, at the international level, gender-neutral programmes are considered less effective because they fail to respond to gender-specific needs of individuals (Gupta, 2000). More importantly, the global prevalence of gender inequality, discrimination, and gender violence, especially towards women, emphasizes the need for genderspecific HIV and AIDS interventions (Middleton-Lee, 2010). The applicability of these comments to the Fiji situation has not been explored fully. Therefore, there is a need to understand the sexual behaviour of Fijians by examining the gender differences that can then help in informing HIV prevention interventions. The aim of the present study is to understand the gender differences in HIV-related knowledge, awareness, attitudes, risk perception, and sexual behaviour among sexually active people in Fiji. In other words, this study aims to answer the question, "how do men and women in Fiji differ in regard to their sexual knowledge, attitudes and behaviours?"

\section{Methodology}

In seeking to identify possible gender differences in sexual attitudes and behaviour, the present study examines individual characteristics of a sample of women and men 
regarding: 1) HIV knowledge and information-seeking behaviour; 2) attitudes towards HIV testing; 3) attitudes towards sex (particularly about multiplicity of sexual partners, premarital sex, and contraceptive use); and 4) self-reported behaviour with respect to sexual practices and condom use. Pre-marital sex is an important predictor of HIV risk (Ghebremichael \& Finkelman, 2013; Mulugeta \& Berhane, 2014; Tekletsadik, Shaweno, \& Daka, 2014).

Information on these areas was elicited by means of a facilitator-guided, selfadministered, structured questionnaire, which had been custom-designed and then adjusted after a pilot study on a sample group of 15 . The questionnaire contained closed, dichotomous or rating questions that did not provide respondents with opportunities to elaborate their answers with qualitative material. The researchers distributed questionnaires to different sectors (i.e. public and private organizations) depending on the number of staff or customers that were present at the study location at the time of survey. Ethics approval was taken in this survey and informed consent was signed by the participants prior to the survey. Confidentiality was maintained by not collecting any information whatsoever on the identity of the respondents, which was also an attempt to reduce social desirability bias. The inclusion criteria was that participants needed to be above the age of 10 years and voluntarily participate in the research.

\section{Study Sample}

A non-probability convenience sampling survey was conducted in two major commercial locations in Fiji - Suva and Nausori. Suva city is the most populous urban conglomerate in Fiji, representing approximately 9\% of Fiji's total population, while Nausori town represents 3\% of Fiji's population (Bureau of Statistics, 2017). The sample of adults were chosen in a convenient manner due to time and budgetary constraints. For this study, the researchers targeted a sample of 200 people working within private-sector business firms (such as hardware stores and boutiques) and public-service organizations or government agencies, as well as people visiting internet cafes and gymnasiums. Prior to data collection, an informed consent was obtained from human resource managers and shop supervisors. In some instances, the HR managers and shop supervisors agreed to act as gatekeepers in the distribution and collection of questionnaires. Apart from ease of access to respondents, convenience sampling technique ensured that we had a good, random mix of participants in the sample. However, this strategy is limited in the sense that only tentative generalizations can be made (Bouma \& Ling, 2004). 
The response rate for this research was 68.5 percent (137/200). Table 1 provides an overview of the demographical characteristics of our respondents. The study sample was represented by 53 percent males and 47 percent females. The median age category of respondents was $26-30$ years $(S D=1.85)$. Single and married people were equally represented in this study (47.4\% single and $46.7 \%$ married, while $1.5 \%$ of the sample were divorced and $2.9 \%$ were in a relationship). The two major ethnic groups were also fairly distributed: 52 percent i-Taukei; 44.5 percent Indo-Fijians (a little higher than the national figure for this group); and 4 percent others. The majority of the respondents were employed (72\%) and approximately $54 \%$ of the sample had tertiary-level qualifications.

Table 1. Demographic Characteristics of Survey Participants $(n=137)$

\begin{tabular}{lll}
\hline Variable & No. & \% \\
\hline Gender & 72 & 52.6 \\
Male & 64 & 46.7 \\
Female & 1 & 0.7 \\
N/A & & \\
Age & 7 & 5.6 \\
10-15 years & 13 & 10.3 \\
16-20 years & 42 & 33.3 \\
$21-25$ years & 27 & 21.4 \\
$26-30$ years & 14 & 11.1 \\
$31-35$ years & 8 & 6.3 \\
36-40 years & 7 & 5.6 \\
41 - 45 years & 4 & 3.2 \\
46-50 years & 4 & 3.2 \\
50+ years & 11 & 8 \\
N/A & & \\
Marital Status & 65 & 47.4 \\
Single & 64 & 46.7 \\
Married & 2 & 1.5 \\
Divorced & 3 & 2.9 \\
In a relationship & 1 & 0.7 \\
De facto union & 2 & 1.5 \\
N/A & & \\
Ethnicity & 71 & 51.8 \\
Fijian & 61 & 44.5 \\
Indo-Fijian & 5 & 3.6 \\
Others & & \\
Occupation & 30 & 5.8 \\
Student & & \\
Unemployed & & \\
\hline & & \\
\hline
\end{tabular}




\begin{tabular}{cll}
\hline Working & 99 & 72.3 \\
Highest Level of Education & & \\
Never educated & 1 & 0.7 \\
Primary school & 4 & 2.9 \\
High school & 58 & 42.3 \\
Tertiary & 74 & 54.0 \\
\hline
\end{tabular}

Source: Authors

\section{Study Questionnaire}

\section{Knowledge}

To assess participants' awareness about HIV, we utilized questions such as "Have you heard of HIV and AIDS?" and "Please provide definitions of HIV". Comprehensive, HIV-related knowledge was measured through questions about HIV symptoms, modes of transmission and prevention techniques. An overall knowledge $(K)$ score was calculated from 13 true-false questions related to HIV transmission. A low score (1-4 points) would indicate very little knowledge about HIV transmission, whereas well-informed individuals would be characterized by scores of 9 points or higher. Further to individual knowledge, we wanted to examine information-seeking behaviour (i.e. efforts and eagerness to learn more about HIV) and determine gender disparities within this aspect of behaviour.

\section{Risk Perception}

Social studies in the field of HIV commonly examine HIV risk perception levels of the target groups being investigated. In the present case, participants were asked whether they considered themselves to be at risk of contracting HIV. Further questions explored whether respondents had previously undergone a HIV test, would have any interest in having an HIV test in the future, and knew where to get tested.

\section{Sexual Attitudes}

Nine statements pertaining to sexual partners, infidelity, sex before marriage and condom use were used to ascertain aspects of participants' sexual attitudes (A). A 5point Likert scale (ranging from strongly disagree [low] to strongly agree [high]) was used to record responses, which were analyzed through independent samples t-test analysis to identify differences in male and female responses.

\section{Self-reported Sexual Behaviour}

Current sexual behaviour (B) of participants was ascertained through questions like 
"Have you ever had sexual relations?", "Have you had sex with more than one partner?" and "Have you ever practised risky sex (sex without condoms)?" Additional questions touched on associated variables, such as condom affordability, rate of condom use, partners' willingness to use condoms, and overall condom use. In the only concession to qualitative explanation, reasons behind individual condom use and non-use were invited. Chi-square analysis was used for all responses, apart from reasons for condom use or non-use.

\section{Data Analysis}

In light of the quantitative nature of the data collected, SPSS software (V.16) was used to perform basic and inferential statistical analyses. Cross-tabulations, chisquare analysis and independent samples $t$-test were used to generate desired results and identify significant values.

\section{Results}

\section{HIV-Related Knowledge, Attitude, and Risk Perception}

Survey results indicated no disparities in HIV and AIDS awareness by gender (Table 1). Although 98.5 per cent of the sample had heard of HIV and AIDS, very few respondents were aware of the definition of HIV and AIDS. Results showed that fewer than 25 per cent of the sample could accurately define HIV and fewer than 50 per cent, AIDS, or identify the symptoms of HIV. However, knowledge about modes of HIV transmission was reportedly high amongst overall study participants. In general, almost three-quarters of the sample received high knowledge scores. Using Chi-square tests for independence, it was established that slight gender variations were present with regard to detailed knowledge about it. For instance, males appeared to be less informed about the use of sterilized instruments, such as needles, to prevent the spread of HIV $(p<0.05$, odds ratio $=0.41)$. Thus, compared to females, the males have 0.41 odds of knowing that using sterilized instruments prevent HIV. 
Table 2. Gender Differences in HIV-related Knowledge, Discussion, and Risk Perception (\%)

\begin{tabular}{|c|c|c|c|c|c|c|}
\hline $\begin{array}{l}\text { Responses to knowledge- } \\
\text { related questions }\end{array}$ & $\begin{array}{l}\text { Males } \\
(\mathrm{n}= \\
72) \\
(\%)\end{array}$ & $\begin{array}{l}\text { Females } \\
(\mathrm{n}=64)(\%)\end{array}$ & $\begin{array}{l}\begin{array}{l}\text { Total } \\
(\mathrm{n}= \\
136) \\
(\%)\end{array} \\
\text { (1) }\end{array}$ & $\begin{array}{l}\text { p- } \\
\text { value }\end{array}$ & $\begin{array}{l}\text { Chi- } \\
\text { Squar } \\
\text { e } \\
\text { Statis } \\
\text { tic }\end{array}$ & $\begin{array}{l}\text { Odds Ratio } \\
\text { (95\% C.I.) }\end{array}$ \\
\hline \multicolumn{7}{|l|}{ General awareness } \\
\hline Has heard of HIV and AIDS & 52.2 & 46.3 & 98.5 & 0.933 & 0.007 & $\begin{array}{l}1.13(0.07 \text { to } \\
18.39)\end{array}$ \\
\hline $\begin{array}{l}\text { Provided correct definition for } \\
\text { HIV }\end{array}$ & 21.8 & 26.3 & 48.1 & 0.072 & 3.229 & $\begin{array}{l}0.53(0.27 \text { to } \\
1.06)\end{array}$ \\
\hline $\begin{array}{l}\text { Provided correct definition for } \\
\text { AIDS }\end{array}$ & 24.8 & 27.1 & 51.9 & 0.182 & 1.780 & $\begin{array}{l}0.63(0.32 \text { to } \\
1.25)\end{array}$ \\
\hline \multicolumn{7}{|l|}{ Knowledge of HIV and AIDS } \\
\hline $\begin{array}{l}\text { Aware of symptoms of HIV } \\
\text { and AIDS }\end{array}$ & 22.8 & 24.4 & 47.2 & 0.345 & 0.893 & $\begin{array}{l}0.71(0.36 \text { to } \\
1.44)\end{array}$ \\
\hline \multicolumn{7}{|l|}{$\begin{array}{l}\text { Know of ways to prevent HIV } \\
\text { and AIDS: }\end{array}$} \\
\hline - $\quad$ Abstain from sex & 18.7 & 17.2 & 35.8 & 0.876 & 0.024 & $\begin{array}{l}0.95(0.47 \text { to } \\
1.92)\end{array}$ \\
\hline - Have one sexual partner & 39.6 & 35.1 & 74.6 & 0.995 & 0.000 & $\begin{array}{l}1.00(0.46 \text { to } \\
2.19)\end{array}$ \\
\hline - Use condoms & 42.5 & 34.3 & 76.9 & 0.319 & 0.991 & $\begin{array}{l}1.51(0.67 \text { to } \\
3.37)\end{array}$ \\
\hline $\begin{array}{l}\text { - Use sterilised instruments } \\
\text { (e.g. needles) }\end{array}$ & 11.9 & 19.4 & 31.3 & $\begin{array}{l}\mathbf{0 . 0 2 0} \\
*\end{array}$ & 5.444 & $\begin{array}{l}0.41(0.20 \text { to } \\
0.88)\end{array}$ \\
\hline \multicolumn{7}{|l|}{$\begin{array}{l}\text { Overall Knowledge Score (13 } \\
\text { T/F statements): }\end{array}$} \\
\hline$-\quad$ Low $(1-4)$ & 2.2 & 3.7 & 6 & \multirow[t]{3}{*}{0.653} & 0.854 & \\
\hline - Moderate (5-8) & 11.2 & 9 & 20.1 & & & \\
\hline$-\quad$ High $(>9)$ & 39.6 & 34.3 & 73.9 & & & \\
\hline \multicolumn{7}{|l|}{ Efforts to learn and discuss } \\
\hline $\begin{array}{l}\text { Attempted to know more about } \\
\text { HIV and AIDS }\end{array}$ & 46.3 & 41.8 & 88.1 & 0.780 & 0.078 & $\begin{array}{l}0.86(0.30 \text { to } \\
2.47)\end{array}$ \\
\hline \multicolumn{7}{|l|}{$\begin{array}{l}\text { Discussion about HIV and } \\
\text { AIDS }\end{array}$} \\
\hline - All the time & 4.5 & 1.5 & 6.1 & \multirow[t]{4}{*}{0.208} & 4.553 & \\
\hline - Sometimes & 32.6 & 25 & 57.6 & & & \\
\hline - Hardly & 13.6 & 15.2 & 28.8 & & & \\
\hline - Never & 2.3 & 5.3 & 7.6 & & & \\
\hline $\begin{array}{l}\text { Talk with friends about HIV } \\
\text { and AIDS }\end{array}$ & 35.6 & 22 & 57.6 & $\begin{array}{l}\mathbf{0 . 0 1 8} \\
*\end{array}$ & 5.585 & $\begin{array}{l}2.33(1.15 \text { to } \\
4.71)\end{array}$ \\
\hline $\begin{array}{l}\text { Talk with family about HIV \& } \\
\text { AIDS }\end{array}$ & 25 & 19.7 & 44.7 & 0.548 & 0.361 & $\begin{array}{l}1.24(0.62 \text { to } \\
2.46)\end{array}$ \\
\hline $\begin{array}{l}\text { Would like to receive HIV- } \\
\text { related information: }\end{array}$ & & & & & & \\
\hline
\end{tabular}




\begin{tabular}{|c|c|c|c|c|c|c|}
\hline - All the time & 29.5 & 16.4 & 45.9 & \multirow[t]{4}{*}{0.138} & 0.618 & \\
\hline - Sometimes & 22.1 & 23.8 & 45.9 & & & \\
\hline - Hardly & 3.3 & 3.3 & 6.6 & & & \\
\hline - Never & 0 & 1.6 & 1.6 & & & \\
\hline \multicolumn{7}{|l|}{ Risk perception } \\
\hline $\begin{array}{l}\text { Consider yourself at risk of } \\
\text { contracting HIV? }\end{array}$ & 17.2 & 6.3 & 23.4 & $\begin{array}{l}\mathbf{0 . 0 1 9} \\
* \\
\end{array}$ & 5.497 & $\begin{array}{l}2.87(1.16 \text { to } \\
7.05)\end{array}$ \\
\hline Has received HIV test before & 13.6 & 14.4 & 28 & 0.482 & 0.494 & $\begin{array}{l}0.76(0.35 \text { to } \\
1.65)\end{array}$ \\
\hline \multicolumn{7}{|l|}{$\begin{array}{l}\text { Is interested in getting HIV } \\
\text { test }\end{array}$} \\
\hline - Yes & 35.8 & 15.6 & 51.4 & \multirow[t]{2}{*}{$\begin{array}{l}\mathbf{0 . 0 0 2} \\
*\end{array}$} & 9.917 & $\begin{array}{l}3.50(1.58 \text { to } \\
7.72)\end{array}$ \\
\hline$-\mathrm{No}$ & 19.3 & 29.4 & 48.6 & & & \\
\hline Knows where to get HIV test & 32.3 & 29.8 & 62.1 & 0.408 & 0.685 & $\begin{array}{l}0.73(0.35 \text { to } \\
1.53)\end{array}$ \\
\hline
\end{tabular}

Note: $*$ indicates p-value $<0.05$

Source: Author's own estimation

Results showed that 92 per cent of the sample wanted to receive HIV-related information "all the time" (45.9\%) or "sometimes" (45.9\%). While 88 per cent of the sample claimed to have tried to be better informed about the disease, there was no statistical evidence to suggest that either gender had made a greater effort than the other. Even the frequency with which the sample discussed HIV and AIDS did not vary significantly between males and females. However, a slight variation was noted in the responses received for discussion about HIV and AIDS with friends. It appeared that males were 2.33 times more likely than females to discuss HIV-related issues with their friends $(p<0.05$, odds ratio $=2.33)$. In the prevailing social ethos, males may be more comfortable handling such issues in public, and could prove to be better advocates than females. The analysis, however, did not present any significant variation between the male and female responses regarding discussion about HIV and AIDS with family members. Researchers like Kaitani (2000) had also observed that the family contributes little to the education of Fijian men about sexual health.

This study presents some notable findings with regard to risk perception differences between male and female respondents. Results indicate that males were 2.87 times more likely to consider themselves at high risk of contracting HIV than females ( $p=$ 0.019 , odds ratio $=2.87)$. Results also show that more than half $(59.4 \%$ ) of respondents did not consider themselves as being at risk of contracting HIV and AIDS; but a significant number of respondents who stated that they were at risk of 
contracting this disease were males. Further investigation on whether respondents had undertaken any HIV tests before produced no statistical evidence to suggest that either one of the gender groups contained a greater number of respondents who had. However, we noted that male respondents were 3.5 times more likely than females to take an HIV test in the future $(p=0.002$, odds ratio $=3.5)$. Therefore, men could easily be convinced through health interventions to agree to be tested. Women, on the other hand, may be reluctant to be tested, disclose a positive diagnosis or access treatment, for fear of a violent reaction from an intimate partner (USAID, 2009).

This study also explored the attitudes of survey respondents towards sexual statements listed in Table 2. Upon conducting the non-parametric Mann-Whitney Utests for such ordinal data, there were significant differences detected in five out of the nine items between the responses of male and female respondents. It is worthwhile to highlight the five statements that produced significant results. As an example, Table 2 reveals that males tended to "disagree" with the statement, "OK to experiment with more than 1 partner" " [mean $=2.132$ ], while females identified with more "strongly disagree" opinions [mean $=1.578$ ], a clear suggestion that women are significantly $(p$-value $=0.022$, Mann-Whitney U Statistic $=1515.0)$ more resistant (on average, a mean difference [Males-Females] of 0.553 with C.I. of 0.151 to 0.956 ) to the idea of experimenting with multiple partners than men. Similar results are observed with the statement concerning sex before marriage.

The differences in the mean response values between male and female groups suggest a milder tendency among males to disagree with the statement, "OK to have sex before marriage". Such attitudinal results would be consistent with the claim that men may be more likely than women to experiment with multiple partners and have sex before marriage.

Table 3. Sexual Attitudes of Survey Respondents

\begin{tabular}{|c|c|c|c|c|c|c|c|c|c|}
\hline \multirow{2}{*}{$\begin{array}{l}\text { Attitudinal } \\
\text { Statements* }\end{array}$} & \multicolumn{3}{|c|}{ Males } & \multicolumn{3}{|c|}{ Females } & \multirow{2}{*}{$\begin{array}{l}\text { p- } \\
\text { value }\end{array}$} & \multirow{2}{*}{$\begin{array}{l}\text { Mann- } \\
\text { Whitney } \\
\text { U } \\
\text { Statistic }\end{array}$} & \multirow[t]{2}{*}{$\begin{array}{l}\text { Mean } \\
\text { Difference } \\
\text { (95\% C.I.) }\end{array}$} \\
\hline & $N$ & Mean & $\begin{array}{l}\text { St. } \\
\text { Dev }\end{array}$ & $N$ & Mean & $\begin{array}{l}\text { St. } \\
\text { Dev }\end{array}$ & & & \\
\hline $\begin{array}{l}\text { Prefer one sexual } \\
\text { partner }\end{array}$ & 70 & 4.257 & 0.988 & 59 & 4.373 & 0.963 & 0.360 & 1891.0 & $\begin{array}{l}-0.116(-0.457 \\
\text { to } 0.226)\end{array}$ \\
\hline $\begin{array}{l}\text { Prefer } 1 \text { sexual partner } \\
\text { for a lifetime }\end{array}$ & 70 & 4.200 & 0.987 & 60 & 4.483 & 0.911 & 0.045 & 1717.5 & $\begin{array}{l}-0.283(-0.615 \\
\text { to } 0.048)\end{array}$ \\
\hline $\begin{array}{l}\text { People need a variety } \\
\text { of sexual partners }\end{array}$ & 69 & 2.044 & 1.322 & 59 & 1.627 & 1.113 & 0.036 & 1650.0 & $\begin{array}{l}0.416(-0.015 \\
\text { to } 0.848)\end{array}$ \\
\hline
\end{tabular}




\begin{tabular}{|l|l|l|l|l|l|l|l|l|l|}
\hline $\begin{array}{l}\text { One partner is } \\
\text { impossible }\end{array}$ & 68 & 2.118 & 1.264 & 58 & 1.776 & 1.109 & 0.091 & 1652.0 & $\begin{array}{l}0.342(-0.081 \\
\text { to } 0.765)\end{array}$ \\
\hline $\begin{array}{l}\text { OK to experiment with } \\
\text { more than 1 partner }\end{array}$ & 68 & 2.132 & 1.337 & 57 & 1.579 & 0.924 & $\mathbf{0 . 0 2 2}$ & 1515.0 & $\begin{array}{l}0.553(0.151 \text { to } \\
0.956)\end{array}$ \\
$\begin{array}{l}\text { OK to have sex before } \\
\text { marriage }\end{array}$ & 68 & 2.397 & 1.329 & 58 & 1.931 & 1.296 & $\mathbf{0 . 0 3 6}$ & 1567.0 & $\begin{array}{l}0.466(0.001 \text { to } \\
0.931)\end{array}$ \\
$\begin{array}{l}\text { OK to have sex in } \\
\text { casual relationships }\end{array}$ & 69 & 2.275 & 1.211 & 59 & 1.864 & 1.181 & $\mathbf{0 . 0 2 9}$ & 1602.5 & $\begin{array}{l}0.411(-0.009 \\
\text { to } 0.831)\end{array}$ \\
\hline $\begin{array}{l}\text { Condoms are very } \\
\text { important during sex }\end{array}$ & 68 & 3.824 & 1.326 & 59 & 3.559 & 1.263 & 0.126 & 1704.0 & $\begin{array}{l}0.264(-0.193 \\
\text { to } 0.721)\end{array}$ \\
\hline $\begin{array}{l}\text { It's OK to have sex } \\
\text { without condoms }\end{array}$ & 67 & 2.239 & 1.383 & 57 & 2.474 & 1.269 & 0.234 & 1682.0 & $\begin{array}{l}-0.235(-0.71 \\
\text { to 0.24) }\end{array}$ \\
\hline
\end{tabular}

Notes: *Attitudinal statements were ranked according to 5-point Likert scale: $(1=$ strongly disagreed; $3=$ undecided; $5=$ strongly agreed). - Cronbach's Alpha $(9$ items $)=0.501$.

Source: Authors' own estimation

\section{Sexual Behaviour and Condom Use}

The enquiries about current sexual behaviour patterns and self-assessments of condom use also produced noteworthy results, presented in Table 4. Nearly 80 percent of the sample reported being sexually active. The demographic information given earlier indicated an almost equal distribution by marital status in the study sample (represented by $47.4 \%$ single and $46.7 \%$ married people; whilst $1.5 \%$ were divorced, $2.9 \%$ in a relationship, $0.7 \%$ were de-facto relationship, and $0.7 \%$ were others). Hence, primary results appear to suggest that single people are engaging in sexual relations. Another significant finding is that males had a 3.21 times higher likelihood of engaging in sexual relations than females $(p=0.011$, odds ratio $=3.21)$. Of the $80 \%$ that reported having engaged in sexual relations, $48 \%$ were males, while only $32 \%$ were females. This is consistent with the data presented in the secondgeneration survey (2008) report, wherein 63 per cent of male tertiary students $(n=$ 180) aged between 15 and 24 years had already had sex, while only 25 per cent of female tertiary students $(n=61)$ reported ever having sex (UNGASS, 2010). In addition, the report highlighted that male STI Clinic attendees, aged between 15 and 25 years, had the highest reported level of first sex before the age of 15 years; whereas female STI Clinic attendees had the lowest reported level of sex before 15 years, followed by antenatal clinic (ANC) attendees (UNGASS, 2010).

Indications are that men are 5.33 times more likely to have multiple sexual partners than women $(p=0.000$, odds ratio $=5.33)$. Many male respondents $(42 \%$ of 136 respondents) reported that they had multiple partners, while only 13 percent of the 
sample females self-reported having engaged in sexual behaviour with multiple partners - a clear basis for the inference that men tend to experiment with multiple partners more than women. In fact, similar findings have been reported in the 2008 second-generation survey report, which reported that the mean number of sexual partners in the past 12 months was highest among male tertiary students (3.8), followed by male STI Clinic attendees (3.6), followed by seafarers (3), uniformed services personnel (2.7), female STI Clinic attendees (1.8), female tertiary students (1.5), and a mean value of 1.1 amongst antenatal clinic attendees (UNGASS, 2010).

Table 4. Differences in Male and Female Response towards Sexual Behaviour and Condom Use

\begin{tabular}{|c|c|c|c|c|c|c|}
\hline Variable & $\begin{array}{l}\text { Males } \\
(\mathrm{n}= \\
72) \\
(\%)\end{array}$ & $\begin{array}{l}\text { Females } \\
(n=64) \\
(\%)\end{array}$ & $\begin{array}{l}\text { Total } \\
(\%)\end{array}$ & p-value & $\begin{array}{l}\text { Chi- } \\
\text { Square } \\
\text { Statisti } \\
\text { c }\end{array}$ & $\begin{array}{l}\text { Odds Ratio }(95 \% \\
\text { C.I.) }\end{array}$ \\
\hline \multicolumn{7}{|l|}{$\begin{array}{l}\text { Current behaviour of } \\
\text { respondents }\end{array}$} \\
\hline Had sexual relations & 48.4 & 32 & 80.5 & $0.011 * *$ & 6.453 & $3.21(1.27$ to 8.13$)$ \\
\hline Had multiple sexual partners & 41.7 & 12.6 & 54.4 & $0.000 * * * *$ & 15.674 & $5.33(2.27$ to 12.53$)$ \\
\hline $\begin{array}{l}\text { Had practised risky sex (sex } \\
\text { without condoms) }\end{array}$ & 31.3 & 5.1 & 36.4 & $0.000 * * * *$ & 17.667 & 8.27 (2.84 to 24.06$)$ \\
\hline \multicolumn{7}{|l|}{ Rate of condom use } \\
\hline $\begin{array}{l}\text { Finds condom affordable } \\
\text { Use condoms with Partner: }\end{array}$ & 34.6 & 19.2 & 53.8 & 0.307 & 1.045 & $0.600(0.22$ to 1.60$)$ \\
\hline - $\quad$ All the time & 8.2 & 0 & 8.2 & $0.052 *$ & & \\
\hline - $\quad$ Sometimes & 23.5 & 13.3 & 36.7 & & 7.733 & \\
\hline - Hardly & 8.2 & 8.2 & 16.3 & & & \\
\hline - Never & 19.4 & 19.4 & 38.8 & & & \\
\hline \multicolumn{7}{|l|}{$\begin{array}{l}\text { When does partner want to use } \\
\text { condoms? }\end{array}$} \\
\hline - $\quad$ All the time & 8.8 & 2.2 & 11 & 0.144 & & \\
\hline - $\quad$ Sometimes & 24.2 & 9.9 & 34.1 & & 5.416 & \\
\hline - $\quad$ Hardly & 8.8 & 7.7 & 16.5 & & & \\
\hline - Never & 18.7 & 19.8 & 38.5 & & & \\
\hline \multicolumn{7}{|l|}{ Overall condom use: } \\
\hline - None & 16 & 22.3 & 38.3 & $0.005 * * *$ & & \\
\hline - Low & 30.9 & 14.9 & 45.7 & & 10.52 & \\
\hline - $\quad$ High & 13.8 & 2.1 & 16 & & & \\
\hline
\end{tabular}

Notes: $* \mathrm{p}$-value $<0.10 ; * * \mathrm{p}$-value $<0.05$; ***p-value $<0.01$; $* * * *$ p-value $<0.001$.

Source: Authors' own estimation

A significantly larger proportion of males than females in this survey reported having practised risky sex or sex without condoms $(p=0.000$, odds ratio $=8.27)$. When our study asked respondents about the rate of condom use with their partner, a higher 
number of males indicated that they used condoms with their partners "all the time" or "sometimes" ( $p=0.052)$. A significantly higher number of males also responded to questions regarding overall condom use. The data indicate that men have a higher tendency to report the use of condoms than females $(p=0.005)$. Previous research elsewhere suggests that boys tend to report using condoms more than girls, while girls are more likely to use female methods such as injectables or oral contraceptives (Varga, 2001). Research by Zeng et al (2015) in China also found that, although health education intervention improved people's knowledge and attitudes about HIV infection, and increased self-reported HIV testing, it did not decrease risky sex (that is, sex without condoms).

\section{Discussion}

This study highlighted several important aspects of sexual behaviour of men and women living in two urban areas of Fiji. First, findings showed that men are more likely than women to talk about HIV-related issues with their friends. This has huge implications for health interventions to use male peer-educators and role models to raise awareness and initiate discussions about HIV and AIDS. Moreover, men can be trained to become advocates for HIV and AIDS awareness within their community, workplace, and their social groups. It would be helpful to develop male advocates from diverse backgrounds who can act as role models and encourage other men in their communities to change their sexual patterns, practice safe sex, and go for HIV testing. Our survey results showed that male respondents were more willing than women to get tested for HIV in the future. These findings imply that investing in the development of male advocates would prove to be a worthy initiative.

Another significant finding is that men are more open than women to the idea of experimenting with multiple partners and having sex before marriage. It was observed that men recorded only slight disagreement with statements suggesting, "it is OK to have sex before marriage and to experiment with more than one partner". Such attitudes are then reflected in their sexual behaviour - meaning that males had a higher tendency to engage in sexual relations before marriage and were more likely to have multiple sexual partners than women. Previous research by Kaitani (2003) reported that, while individuals and formal precept disapprove of premarital sex, a large proportion of unmarried people are involved in sexual relationships. It is a global trend that men have more sex partners than women (CPHA, 2001; Henderson, Lieb, McKinley-Beach, \& LaLota, 2009), which eventually places them and their sex partners at increased risk of sexually transmitted infections (Varga, 2001). In 
addition, men initiate sexual activity earlier than women. It has been highlighted that young men in Fiji initiate sex between the ages of 9 and 13 years, due to peer pressure and social norms that push them take unnecessary risks (Kaitani, 2003). In other areas, such as Sub-Saharan Africa for instance, studies have found that boys and young men initiate sex earlier than girls, have more sexual partners and engage in intercourse more often, and are more likely to report having an STD infection (Varga, 2001).

Our results also show that nearly one in every three men had practised sex without condoms. While a higher number of male respondents reported the use of condoms with their partner, the overall use of condoms among men was low, or none at all. Findings from this survey are consistent with the 2008 second-generation survey that found that over fifty per cent of respondents from each sub-population that had been surveyed (including ANC attendees, seafarers, and uniformed service respondents) reported "never using condoms" in the previous 12 months (UNGASS, 2010). A study by McMillan and Worth (2010) additionally states that many clients of sex workers often do not want to use condoms, pressurise sex workers into having intercourse without condoms, or offer more money for sex without a condom. The use of condoms is also reportedly low among minority groups such as gay, bisexual, and transgender people. A recent report launched by the United Nations Development Programme in Fiji reported that, despite high levels of HIV knowledge among marginalised groups, only $14.8 \%$ of 212 study participants reported frequent condom use when having sex with straight male partners, while only one-third of respondents revealed that they frequently used condoms with gay or transgender partners (Bavinton et al., 2011). A separate study conducted in Fiji by Hammar et al. (2011) among marginalised groups, taxi drivers, sex workers, university students, health care workers, and Christian pastors reported that only 25\% (18 out of 73) of respondents had used a condom at last sexual encounter. A survey on re-infected patients at Suva STI Clinic showed that $88 \%$ of individuals knew that condoms prevent STI, but only 5\% had used condoms at their last sexual encounter (Hotchin et al., 1995, as cited in Kaitani, 2003).

It is evident that young men in Fiji engage in risky sexual behaviour. Our survey shows that men's reasons for not using condoms include factors such as inconsistent supply, dislike for the product, and moral reasons. Local researchers have highlighted barriers such as prevailing myths around condom use that creates a negative impression of contraceptive use amongst youths (MSIP, 2007). Furthermore, social taboos (code of silence on sexual and reproductive health) restrict open discussions around sex and condom use in Fiji and most Pacific Island countries (MSIP, 2007; 
Ratu \& Kumar, 2008). Ratu and Kumar (2008) further reported that excessive yaqona $^{2}$ (or kava) consumption often led to intoxication and resulted in risky behaviour among men. It is also not uncommon for men to engage in unsafe sex due to alcohol intoxication, substance abuse (e.g. marijuana), social norms around masculinity and virility, peer pressure, and personal ignorance of sexually transmitted diseases (FRCS, 2010; Jenkins \& Buchanan-Aruwafu, 2007; Lukere, 2002). Other modern factors, as observed by Hammar et al. (2011), include declining traditions and moral values among the younger generation; breakdown of the family; sexualisation of female youths; high levels of movement; influence of westernderived music, adult movies, and X-rated magazines; as well as greater accessibility of the internet through widely available broadband modems and cell phones, allowing people to access social networking sites and pornography. It is possible for factors such as actual or perceived disadvantages of condom use, prior negative use, inexperience, or gender or social inequalities (Warner, Gallo, \& Macaluso, 2012) to act as barriers to effective condom use among sexually active men in Fiji. Further research is required to ascertain the extent of the impact of the different risk factors on men's sexual behaviour.

\section{Study Limitations}

Since the survey area was confined to the two central, highly urbanised regions of Fiji, it may be inapt to generalise the study findings to youth living in less populous urban areas, rural areas or remote locations. Young people residing in rural areas may not have the same amount of exposure to resources that are usually available in urban areas (for example, education \& communication materials on sexual and reproductive health, computers that provide access to internet or limited mobile internet data, or other information sources such as newspapers and television). Family, community and peer pressures are also exerted differently in rural areas. In addition, responses collected in this survey were mostly from young people who were working; thus, there is little representation of tertiary students and unemployed youth. Moreover, the strategy of using HR managers and shop supervisors to distribute questionnaires among the target group may have involved managers' personal bias in distributing questionnaires to people based on familiarity, availability, age group, or status within the organisation. Although such bias may not significantly influence the overall sample, there is often a risk of response bias when questionnaires are self-completed by respondents in their own time and space. There is no way to tell if participants provided their own answers or consulted other sources,

\footnotetext{
${ }^{2}$ Yaqona drink is prepared from the pulverized root of Piper Methysticum plant, and it is consumed during traditional ceremonies and/or during leisure time with friends or relatives.
} 
such as friends and/or the internet, to answer HIV-related questions. Lastly, the study acknowledges the absence of data regarding sexual preference of respondents, which would have provided additional behavioural insights.

Future KAPB studies (targeting knowledge, attitude, risk perceptions, and behaviour regarding HIV) could focus on larger, more geographically diverse sample groups, with some emphasis on rural areas. Enquiry beyond these areas and among workers in the informal sector and the civil service, as well as the unemployed, remains for the future. It needs also to be noted that the constraints also governed the decision to employ only an instrument amenable to quantitative analysis. Formal measures of HIV knowledge and attitude can be utilized by future studies to increase data validity and reliability.

\section{Implications for Health Policy, Research and Practice}

Given that some gender variations are observed in HIV knowledge, although not significant, it is necessary to continue with advocacy work, as well as offer advanced education workshops to disseminate accurate and timely information among individuals of reproductive age. This could be ideally implemented by recruiting more males as peer educators, as the study showed that males are more comfortable in discussing HIV- related topics and also able to address knowledge gaps, such as that related to injectables, which is more common amongst males. The finding that males are more comfortable discussing HIV-related topics may also imply that females need particularly more training to discuss and share knowledge amongst their peers on this issue.

Females' reluctance for the uptake of HIV testing is significant and suggests professional counselling in health practice to increase its uptake and that they need to be educated on its importance. Sexuality education should be high on the agenda of education ministry, with support from health ministry, and contraceptives should be readily accessible and affordable, particularly to improve access to male condoms, noting male's higher odds of engaging in sexual relations and multiplicity of partners. Finally, data suggest that contraceptive methods utilized by females rarely protect them against HIV or STI, and thus females should be made aware and give due regard to protection and not contraception alone.

Further research is needed to examine attitudes and sexual behaviour among young people living in rural areas, unemployed youth, as well as youths working in the informal sector. Another potential area of study is the examination of multiple dimensions of male and female sexual behaviour: for instance, sexual partner 
preference, sexual practices, underlying motives for sex, attitudes towards sex, and individual perception of contracting sexually transmitted infections. This study opted to investigate the differences in HIV risk perception between males and females, but the findings on these matters were only marginally significant.

\section{Conclusion}

In a developing country such as Fiji, differences exist in the way men and women calculate their risk of contracting HIV, their tendency to discuss HIV-related issues with their peers, their attitudes towards moral sexual behaviour, and their actual sexual practices. The present study concentrated on only some of these areas. More importantly, it was an initial quantitative survey rather than an in-depth qualitative study. Such gender differences in sexual attitudes and behaviour, especially when understood in greater depth, must be taken into account when developing HIV prevention programmes, because they highlight areas that require intervention. This study found that although men engage in risky sexual practices with multiple partners, they are more likely than women to discuss the topic of HIV amongst their peers and they are also becoming keener to contemplate being tested for HIV. These findings can be interpreted as a positive sign that men are contemplating change and interventions must be developed accordingly to facilitate positive behaviour change. In particular, male-specific HIV prevention programmes may be required to address the specific needs of young boys and men and to enable them to adopt appropriate attitudes and behaviours that will safeguard their sexual health and that of their partners.

An integrative approach that encompasses effective communication messages, service delivery, and supply mechanisms will be necessary to address multiple barriers to behaviour change. This study notes that one of the reasons why male respondents do not use condoms is that they are not always available. In order to promote consistent use of condoms among sexually active men, health authorities will need to ensure widespread availability, consistent supply, and adequate marketing of the product and its distribution sites. In Fiji, some NGOs train youth peer-educators to conduct workshops and advocacy programmes that disseminate information on sexual and reproductive health. This is the right step forward, but greater efforts should be directed towards developing gender-specific and transformative approaches that can address multiple issues of HIV. Men need to be increasingly considered as part of the solution and engaged as partners in prevention efforts. 


\section{References}

Absalon, J., Fuller, C. M., Ompad, D. C., Blaney, S., Koblin, B., Galea, S., \& Vlahov, D. (2006). Gender differences in sexual behaviors, sexual partnerships, and HIV among drug users in New York City. AIDS and Behavior, 10(6), 707715 .

ADB (2006). HIV/AIDS in the Pacific. Asian Development Bank. Retrieved from http://www.adb.org/Projects/HIV-AIDS/Documents/HIV-AIDSprn2.pdf.

Aspy, C.B., Vesely, S.K., Oman, R.F., Rodine, S., Marshall, L., \& McLeroy, K. (2007). Parental communication and youth sexual behaviour. Journal of Adolescence, 30(3), 449-466.

Bavinton, B., Singh, N., Naiker, D. S., Deo, M. N., Talala, M., Brown, M., Singh, R. R., Dewan, S., \& Navokavokadrau, S. (2011). Secret Lives, Other Voices: A community-based study exploring male-to-male sex, gender identity and HIV transmission risk in Fiji. Suva, Fiji: AIDS Task Force of Fiji.

Boender, C., Santana, D., Santillán, D., Hardee, K., Greene, M., \& Schuler, S. (2004). The 'So What' Report: A look at whether integrating a gender focus into programs makes a difference to outcomes. Washington, DC: Interagency Gender Working Group Task Force.

Bouma, G.D., \& Ling, R. (2004). The Research Process (5 ${ }^{\text {th }}$ Edition). South Melbourne, Australia: Oxford University Press.

Browning, J.R., Hatfield, E., Kessler, D., \& Levine, T. (2000). Sexual motives, gender, and sexual behavior. Archives of Sexual Behavior, 29(2), 135-153.

Buchanan-Aruwafu, H. (2007). An integrated picture: HIV risk and vulnerability in the Pacific: research gaps, priorities and approaches. The Secretariat of the Pacific Community. Retrieved from http://www.fsm.ac.fj/files/An\%20Integrated\%20Picture$\% 20$ HIV\%20Risk\%20and\%20Vulnerability\%20in\%20the\%20Pacific.pdf.

Bureau of Statistics. (2018). 2017 Population and Housing Census. Publication by Fiji Islands Bureau of Statistics. Retrieved from http://www.statsfiji.gov.fj/census.

Canadian Public Health Association [CPHA] (2001). Critical issues in HIV 
prevention: A discussion of heterosexual men and HIV prevention. Retrieved from http://library.catie.ca/PDF/P9/19370e.pdf.

Connell, J., \& Negin, J. (2010). Migration, mobility and HIV: A rapid assessment of risks and vulnerabilities in the Pacific. Joint United Nations Development Programme (UNDP) and Secretariat of the Pacific Community (SPC) publication. Retrieved from http://www.undppc.org.fj/_resources/article/files/Migration,MobilityandHI V_web.pdf.

De Gaston, J. F., Weed, S., \& Jensen, L. (1996). Understanding gender differences in adolescent sexuality. Adolescence, 31(121), 217-232.

DiClemente, R. J., Wingood, G. M., Rose, E. S., Sales, J. M., Long, D. L., Caliendo, A. M., \& Crosby, R. A. (2009). Efficacy of sexually transmitted disease/human immunodeficiency virus sexual risk reduction intervention for African American adolescent females seeking sexual health services: A randomized controlled trial. Archives of Pediatric and Adolescent Medicine, 163, 1112-1121. doi:10.1001/archpediatrics .2009.205.

Fiji Red Cross Society [FRCS]. (2010). Strategic Plan 2010-2014. Fiji Red Cross

Society, Suva. Retrieved on from

http://www.redcross.com.fj/components/com_pdf/pdfs/Strategic\%20Plan\%202 010-2014.pdf.

Fiji Ministry of Health \& Medical Services (2016). Fiji HIV \& AIDS Response Progress Report-Monitoring Progress towards the Targets of the 2011 UN Political Declaration on HIV \& AIDS. Retrieved from https://www.unaids.org/en/file/110928/download?token=NYrifbYg.

Fowler, D., O’Loughlin, B., \& Tikinatabua, V. (2007). Mid-term review of the Pacific Regional Strategy on HIV (2004-2008) and its implementation - Final Report. Secretariat of the Pacific Community. Retrieved from http://www.spc.int/hiv/downloads/behaviour-change-communication/

Ghebremichael, M. S., \& Finkelman, M. D. (2013). The effect of premarital sex on sexually transmitted infections (STIs) and high risk behaviors in women. Journal of AIDS and HIV research (Online), 5(2), 59-64. 
Gupta, G. R. (2000). Gender, Sexuality, and HIV/AIDS: The What, the Why, and the How. Plenary Address at the XIIIth International AIDS Conference (12 July 2000), Durban, South Africa.

Hammar, L., Gucake, J., Kumari, R., Bui, S., Turagaiviu, V., \& Gadolo, V. (2011). Me, my intimate partner, and HIV: Fijian self-assessments of transmission risks. United Nations Development Programme Pacific Centre, Suva, Fiji. Retrieved from http://www.asiapacific.undp.org/content/dam/rbap/docs/Research\%20\&\%20Publications/h iv_aids/rbap-hhd-2011-me-my-intimate-partner-and-hiv.pdf .

Hammar, L., Gucake, J., \& Strobel, F. (2013). Learning (at) our place: Qualitative research methods and researchers strengthen Fiji's national response to HIV and AIDS. Asia Pacific World, 4(1), 80-104.

Harrison, A., Xaba, N., \& Kunene, P. (2001). Understanding safe sex: Gender narratives of HIV and pregnancy prevention by rural South African school-going youth. Reproductive Health Matters, 17, 63-71.

Henderson, R., Lieb, S., McKinley-Beach, L., \& LaLota, M. (2009). MAN UP: The Crisis of HIV/AIDS Among Florida's Men. Bureau of HIV/AIDS, Florida Department of Health. Retrieved from http://www.doh.state.fl.us/disease_ctrl/aids/Docs/Man_Up_Report.pdf.

Hotchin P., Tapelu P., Chetty V., Hakwa R., and Philip D. (1995). Knowledge, attitudes and behaviours of reinfected patients - Suva STD Clinic, Fiji 1994/95. Pacific Dialogue, 2(2), 45-50.

Jenkins, C., \& Buchanan-Aruwafu, H. (2007). Cultures and Contexts Matter Understanding and Preventing HIV in the Pacific. Asia Development Bank, Manila. Retrieved from http://www.adb.org/Documents/Books/CulturesContexts-Matter/Cultures-Contexts-Matter.pdf.

Kaitani, M. (2000). Safe sex: Knowledge, practice and the contradictions: a case study of Fijian men in urban Suva. Secretariat of the Pacific Community, Suva, Fiji.

Kaitani, M. (2003). Bridging the gap: the changing reproductive and sexual expectations of Fijian men. $\mathrm{PhD}$ thesis, The Australian National University, Canberra. 
Lerdboon, P., Pham, V., Green, M., Riel, R., Tho, L. H., Ha, N. T. V., \& Kaljee, L. M. (2008). Strategies for developing gender-specific HIV prevention for adolescents in Vietnam. AIDS Education and Prevention, 20(5), 384-398.

Lincoln, J., Mohammadnezhad, M., \& Khan, S. (2018). Knowledge, attitude, and practices of family planning among women of reproductive age in Suva, Fiji in 2017. Journal of Women's Health Care, 7(3). DOI: 10.4172/21670420.1000431 .

Lukere, V. (2002). Gender, Women and Mothers: HIV/AIDS in the Pacific. Working Paper No. 7, Gender Relations Center, The Australian National University.

March, C., Smyth, I., \& Mukhopadhyay, M. (1999). A Guide to GenderAnalysis Frameworks. London, UK: Oxfam Great Britain..

McMillan, K., \& Worth, H. (2010). Risky business: sex work and HIV prevention in Fiji. International HIV Research Group, University of New South Wales, Sydney.

Meleisea, P. S. (2010). Gender and HIV in the Pacific Islands Region. United Nations Development Programme, Pacific Centre. Retrieved from http://www.undppc.org.fj/_resources/article/files/HIVandGender.pdf

Mensch, B., Bruce, J., \& Greene, M.E. (1998). The Uncharted Passage: Girls' adolescence in the developing world. New York: Population Council.

Middleton-Lee, S. (2010). Approaches to Gender and Sexuality: Responding to HIV. International HIV/AIDS Alliance. Retrieved from http://www.aidsalliance.org/includes/Publication/GenderAndSexua lityReport.pdf.

Ministry of Health (MoH) (2007). Fiji National HIV/AIDS Strategic Plan 20072011.

Ministry of Health Fiji (2014). Global AIDS progress report 2013: Fiji Islands. Retrieved from https://www.unaids.org/sites/default/files/country/documents/FJI_narrative report_2014.pdf

Morrison, L. (2004). Traditions in transition: Young people's risk for HIV in Chiang Mai, Thailand. Qualitative Health Research, 14(3), 328-344. 
MSIP [Marie Stopes International Pacific] (2007). Annual Report for NZAID Condom Social Marketing Project - Fiji, Samoa and Tuvalu.

Mulugeta, Y., \& Berhane, Y. (2014). Factors associated with pre-marital sexual debut among unmarried high school female students in bahir Dar town, Ethiopia: cross-sectional study. Reproductive health, 11(40). doi:10.1186/1742-4755-11-40.

Nahom, D., Wells, E., Gillmore, M. R., Hoppe, M., Morrison, D. M., Archibald, M., Murowchick, E., Wilsdon, A., \& Graham, L. (2001). Difference by gender and sexual experience in adolescent sexual behavior: implications for education and HIV prevention. Journal of School Health, 71(4), 153-158.

Oceania National Olympics Committees (ONOC) (2008). STOP HIV Annual Report.

Pan, Y., Metsch, L.R., Wang, W., Duan, R., Kyle, T.L., Gooden, L.K., \& Feaster, D.J. (2016). Gender differences in HIV sexual risk behaviors among clients of substance use disorder treatment programs in the U.S. Archives of Sexual Behavior, 46(4), 1151-1158.

Parkes, A., Wight, D., Hunt, K., Henderson, M., \& Sarjent, J. (2013). Are sexual media exposure, parental restrictions on media use and co-viewing TV and DVDs with parents and friends associated with teenagers' early sexual behaviour? Journal of Adolescence, 36(6), 1121-1133.

Ram, S. (2018). Perceptions of teachers, parents and students regarding the delivery of Sexual and Reproductive Health ( SRH ) Education in secondary schools in Fiji , 2018: A Qualitative Study. (Published masters dissertaton). Fiji National University, Suva.

Ratu, S., \& Kumar, V. (2008). Together We Can Project: Bi Annual Progress Report 2/ Mid Term Report. Prepared for Asia Development Bank.

Ricardo, C., Barker G., Pulerwitz J., and Rocha V. (2006). Gender, sexual behavior and vulnerability among young people. In Ingham, R. and Aggleton, P. (eds) Promoting Young People's Sexual Health. London: Routledge.

Rimal, R., Brown, J., Mkandawire, G., Folda, L. Böse, K. \& Creel, A. H. (2009). Audience segmentation as a social-marketing tool in health promotion: use of the risk perception attitude framework in HIV prevention in Malawi. American Journal of Public Health, 99(12), 2224-2229. 
Schueller, J., Finger, W., \& Barker, G. (2005). Boys and changing gender roles: Emerging program approaches hold promise in changing gender norms and behaviours among boys and young men. Washington, DC: Youth Net.

Secretariat of the Pacific Community [SPC] (2010). STI Epidemiological Update PICTs 2009: HIV \& STI Surveillance. Retrieved from https://www.aidsdatahub.org/sites/default/files/documents/Secretariat_of the Pacific_Community_(2010)_STI_Epidemiological_Update_for_Pa cific_Island_Countries_2009_.pdf

Sun, C.J., Seloilwe, E.S., Magowe, M., Dithole, K.S., Miller, K.S., \& Lawrence, S. (2018). Gender Differences in Sexual and Reproductive Health Protective and Risk Factors of Batswana Adolescents: Implications for Parent and Adolescent Interventions. AIDS Education and Prevention, 30(1), 35-46.

Techasrivichien, T., Darawuttimaprakorn, N., Punpuing, S., Musumari, P.M., Lukhele, B.W., El-saaidi, C., Suguimoto, S.P., Feldman, M.D., Kihara, O., \& Kihara, M. (2016). Changes in sexual behavior and attitudes across generations and gender among a population-based probability sample from an urbanizing province in Thailand. Archives of Sexual Behavior, 45(2), 367-382.

Tekletsadik, E., Shaweno, D., \& Daka, D. (2014). Prevalence, associated risk factors and consequences of premarital sex among female students in Aletawondo High School, Sidama Zone, Ethiopia. Journal of Public Health and Epidemiology, 6(7), 216-222.

UNAIDS (2008). Country Review - Fiji Islands. Retrieved on 20 January 2019 from http://www.aidsdatahub.org

UNAIDS (2010). Global report: UNAIDS report on the global AIDS epidemic 2010. Joint United Nations Programme on HIV/AIDS. Retrieved from http://www.aidsdatahub.org

UNAIDS (2012). Global AIDS Progress Report 2012 - Fiji Islands. Retrieved from http://www.unaids.org/en/dataanalysis/monitoringcountryprogress/progre ssreports/2012countries/ce_FJ_Narrative_Report.pdf.

UNAIDS, UNICEF, WHO, \& ADB (2010). Country review: Fiji Islands. United Nations Joint Programme on HIV/AIDS. Retrieved from 
www.aidsdatahub.org.

UNESCO (2015). Attitudinal Survey Report on the Delivery of HIV and Sexual Reproductive Health Education in School Settings in Palau.

UNICEF Pacific (2013). The status of HIV Prevention, Sexuality and Reproductive Health Education: Fiji, Kiribati, Solomon Islands and Vanuatu. Retrieved from

https://www.unicef.org/pacificislands/SRH_education_review_report_final.pdf

UNFPA (2005). State of the World Population: The Promise of Equality Gender Equity, Reproductive Health and the Millennium Development Goals. New York: UNFPA.

UNGASS (2010). UNGASS 2010 Country progress report Fiji Islands - Reporting period: January 2008 - December 2009. Retrieved from

http://www.unaids.org/en/dataanalysis/monitoringcountryprogress/2010prog ressreportssubmittedbycountries/fiji_2010_country_progress_report_en.pdf.

USAID (2009). Integrating Multiple Gender Strategies to Improve HIV and AIDS Interventions: A Compendium of Programs in Africa. International Center for Research on Women, US Agency for International Development, Washington.

Varani-Norton, E. (2014). It's good to teach them but.. they should also know when to apply it: Parents' views and attitudes towards Fiji's Family Life Education Curriculum. Sex Education, 14(6), 692-706.

Varga, C. A. (2001). The forgotten fifty per cent: A review of sexual and reproductive health research and programs focused on boys and young men in sub-Saharan Africa. African Journal of Reproductive Health, 5(3), 175-195.

Warner, L., Gallo, M. F, \& Macaluso, M. (2012). Condom use around the globe: How can we fulfill the prevention potential of male condoms? Sexual Health, 9, 4-9.

Whitley, B. E. (1988). The relation of gender-role orientation to sexual experience among college students. Sex Roles, 19(9-10), 619-638.

Wiederman, M. W. (1997). The truth must be in here somewhere: Examining the 
gender discrepancy in self-reported lifetime number of sex partners. The Journal of Sex Research, 34(4), 375-386.

World Health Organization [WHO] (2018a). Report on global sexually transmitted infection surveillance, 2018. Retrieved from https://www.who.int/reproductivehealth/publications/stis-surveillance2018/en/

World Health Organization [WHO] (2018b). HIV data and Statistics for Fiji, country profiles on HIV. Retrieved from: http://www.wpro.who.int/southpacific/programmes/communicable_diseases /sexually_transmitted_infections/page/en/.

Yoon, S., Voithb, L.A., \& Kobulskyc, J.A. (2018).Gender differences in pathways from child physical and sexual abuse to adolescent risky sexual behavior among high-risk youth. Journal of Adolescence, 64(2) 89-97.

Zeng H., Zhao Y., Meng S., Tang X., Guo H., Wang Y., and Zhang L. (2015). Exploring HIV Prevention Strategies among Street-Based Female Sex Workers in Chongqing, China. International Journal of Environmental Research and Public Health, 12, 855-870. 